\title{
Trade and Income Convergence: Sorting Out the Causality
}

\author{
Xuepeng Liu \\ Department of Economics and Finance \\ Coles College of Business \\ Kennesaw State University \\ E-mail:xliu6@kennesaw.edu
}

May, 2007

\begin{abstract}
This paper studies the linkage between international trade and income convergence across countries. Different theories offer conflicting predictions regarding how they might affect each other. In the existing empirical literature estimating the trade impact on income convergence, a long-lasting problem is the reverse causality from income convergence to trade. This paper provides a disaggregated bilateral trade data analysis to solve this problem. The results show that the reverse causality from income convergence to trade exists in differentiated product sectors, but not in homogeneous product sectors. Trade in homogeneous sectors reduces the income gaps among trade partners, but it is not significantly affected by their income difference. Therefore the negative effect of trade in homogeneous sectors on income gap is free from the reverse causality problem. It can be taken as the pure evidence of trade-induced income convergence. This result is robust to various econometric methods.
\end{abstract}

Keywords: Trade, income convergence, causality

JEL Classification: F1, F4, O4

\section{Introduction}

Income convergence across countries has been a fascinating subject of research for decades in growth and development economics, especially after the seminal work of Solow (1956). The original Solow model predicts that, due to decreasing returns to capital, income levels across countries converge conditional on their saving rates, population growth and technologies. Despite of the seemingly increasing income gaps across countries after the World War II and the critiques from the new growth theory, the implications of the Solow model for conditional income convergence has received strong empirical support. ${ }^{1}$ The original Solow model, however, is in a closed economy setting and most of the early research on income convergence neglects the role of trade. 
International trade after the World War II has been increasing sharply due to lower transportation costs and trade barriers. Trade not only fundamentally alters the production and consumption patterns of trading nations, but also influences national economies by imposing more rigorous competition, facilitating the spillover of technologies and the exchange of ideas, constraining the government's domestic policies and harmonizing international rules and institutions. It is important to understand whether and how international trade might affect income convergence.

Different theories on their linkages, however, provide conflicting predictions. It is largely an empirical question how trade might affect income convergence. Similar to the theoretical literature, the existing empirical studies also offer mixed results on the impact of trade on income convergence. A long-lasting problem in the existing empirical studies is that the causality between income convergence and trade liberalization has not been well established. The statistical correlation between trade and income convergence does not necessarily imply causality. Without sorting out the causality, there is little to say about the intertwined relationship between trade and income convergence.

In this paper, I adopt a bilateral trade analysis to address the reverse causality problem. Instead of using aggregate trade data, I take advantage of the disaggregated trade data that provide a convenient way to sort out the causality. The idea goes as follows. Although the linkage between aggregate bilateral trade and income convergence could be bi-directional, disaggregated trade in certain sectors might not suffer from the reverse causality problem. According to the Rauch's product classification (Rauch, 1999), this paper shows that trade in both homogeneous and differentiated sectors significantly reduces income gaps between trade partners; and countries with similar income levels 
trade more only in differentiated goods but not in homogeneous goods. These results imply that the reverse causality problem from income convergence to trade is absent, at least less likely, in homogeneous sectors. Therefore, the negative impact of trade in homogeneous sectors on income gaps could be considered as the pure evidence of tradeinduced income convergence. This finding is robust to different econometric methods.

The rest of this paper is organized as follows. In Section 2, I review the theoretical and empirical literature on trade and income convergence. In Section 3, I discuss the empirical strategies to resolve the causality problem between trade and convergence. Section 4 describes the data and their sources. Section 5 shows the empirical results. Some robustness checks are performed in Section 6. Section 7 concludes.

\section{Literature review}

\subsection{Theoretical literature on trade and income convergence}

In the existing theoretical literature, trade and income convergence can affect each other; and the effect in either direction can be positive or negative. The primary goal of this paper is to solve the reverse causality problem between them. Therefore the literature on their linkage in both directions will be discussed.

Trade can affect income gaps not only through factor prices and factor accumulation, but also through technology spillovers. Existing theories show that trade in some ways converges the income levels across countries but in other ways diverges them. Firstly, international trade can affect factor prices and factor accumulation according to several classic trade theories. The factor price equalization theorem (FPE) by Samuelson (1948) states that, under certain conditions, free trade in goods and services can equalize factor 
prices and lead to income convergence. FPE no longer holds, however, when countries' factor endowments lie outside FPE cones. For example, Deardorff (2001) shows that countries having diverse initial endowments may end up with unequal factor prices in different diversification cones. The Stolper-Samuelson theorem says that trade benefits abundant factors by raising their prices, but hurts scarce factors by lowering their prices. On one hand, it implies that trade can raises (reduces) wages in poor (rich) countries and cause income convergence. On the other hand, trade reduces (raises) capital returns and discourages (encourages) investment in poor (rich) countries, which can lead to income divergence (e.g., Baldwin, 1992). In an open economy, the Rybczynski theorem together with the FPE implies that an increase in investment can change a country's output mix without reducing its capital returns. The diminishing returns to investment, as the key to income convergence in the closed-economy Solow model, may no longer hold under free trade (e.g., Ventura, 1997). ${ }^{2}$ Secondly, trade can cause income convergence through technology spillovers, as shown by Grossman and Helpman (1991) and Ben-David and Loewy (1998). ${ }^{3}$ Although Grossman and Helpman find that trade causes faster growth in poor countries in general, there are cases where trade and competition may cause income divergence by discouraging research in poor countries. Young (1991) also shows that a poor country may suffer from trade liberalization due to the dynamic losses from trade, despite of its static gains. Poor countries may finally be caught in poverty traps by specializing in sectors with little potential for technology growth and scale economies. Similar arguments based on the dynamic effects of trade can be found in Matsuyama (1992), Feenstra (1996), Redding (1998) and the early literature on infant industry argument. Finally, Baldwin et al (2001) and Nakajima (2003) among others show that 
divergence or convergence may occur at different stages of trade liberalization or among different groups of countries. Without being exhaustive, these papers overall show no determinate theoretical links from trade to income convergence.

Regarding the impact of income convergence on trade, the conclusions from existing theories are also ambiguous. According to the standard two-factor Heckscher-Ohlin (H-O) model, countries with different income levels trade more with each other based on their differences in capital and labor endowments. The Ricardian model has a similar prediction due to different productivity across countries. The new trade theory based on monopolistic competition and economies of scale, however, shows that countries with different income levels may trade less with each other due to smaller intra-industry trade (e.g., Krugman, 1979; Helpman, 1980). Krugman and Helpman's conclusion is consistent with the Linder hypothesis. It states that countries with similar income levels produce and consume products with similar quality and hence trade more with each other (Linder, 1961). Similar to the Linder hypothesis, models with non-homothetic preference as in Markusen (1986) predict that rich countries produce and consume disproportionably larger amount of high income elastic products (e.g., luxuries) than low income elastic products (e.g., necessities) and vice versa for poor countries. Hence countries with similar income levels trade more due to their similar tastes. ${ }^{4}$

Given the above conflicting predictions from theories, the relationship between trade and income convergence becomes an empirical question. ${ }^{5}$

\subsection{Empirical literature on trade and income convergence}


Parallel to the theoretical literature, the empirical findings on the relationship between trade and income convergence are also mixed, i.e., the effect in either direction can be positive or negative.

A number of papers have studied empirically how trade liberalization might affect income convergence. These studies have so far provided inconsistent results. On one hand, some studies provide evidence that trade liberalization has caused income convergence across countries. ${ }^{6}$ Rassekh (1992) finds that international trade contributed to income convergence among OECD countries during 1950-1985. Ben-David (1993) examines the episodes of major postwar trade liberalization within specified groups of countries and finds a strong positive link between the timing of trade reform and income convergence among these countries. Another paper by Ben-David (1996) focuses on the groups of countries comprising major trade partners. He finds that these major trade partners exhibited significant income convergence, while randomly selected countries were less likely to converge. In an influential study, Sachs and Warner (1995) classify each countries as either "open" or "closed" based on a number of criteria and conclude that open economies display a strong tendency towards economic convergence. The first wave of globalization in late 19th century has been studied by Williamson (1996) and O'Rourke et al (1996). They conclude that the globalization of commodity and factor markets played a critical role in the convergence among OECD economies. In a recent paper, Cyrus (2004) also finds the evidence of trade-induced convergence from her bilateral trade panel data analysis.

On the other hand, some other papers dispute the convergence findings. Slaughter (1998) adopts a difference-in-difference analysis and finds no systematic link between 
four postwar multilateral liberalization episodes and income convergence. Rodriguez and Rodrik (2000) also provide a skeptical view on trade-induced growth and convergence. They observe that most trade liberalization episodes since the $19^{\text {th }}$ century had experienced income divergence. Milanovic (2006) shows that income convergence actually accelerated during the inter-war trade disintegration period (1919-1939).

The existing empirical literature on how income convergence might affect trade largely focuses on testing the Linder hypothesis or non-homothetic preference, i.e., whether countries with similar income levels trade more with each other. Although studies using aggregate trade data in general find empirical support for the Linder hypothesis (e.g., Thursby and Thursby, 1987; Hunter and Markusen, 1988; Hunter, 1991; McPherson et al, 2001), some papers provide the opposite finding (e.g., Hoftyzer, 1984; Hallak, 2006). ${ }^{7}$ Hallak (2006) argues that the Linder hypothesis is about the quality variation within sectors, while aggregate trade analyses include both within-sector and cross-sector variations. The cross-sector determinants of trade as suggested by the $\mathrm{H}-\mathrm{O}$ or Ricardian model operate in the opposite direction from those behind the Linder hypothesis. An aggregate trade analysis is misleading as it combines these conflicting forces. Using disaggregated bilateral trade data for 1995, Hallak (2006) finds that the "sectoral Linder hypothesis" is strongly supported in differentiated sectors, but is rejected in homogeneous sectors at 3-digit SITC level.

In summary, the existing empirical studies estimating the impact of trade on convergence and those estimating the impact of convergence on trade are largely separated from each other. Obviously, these papers are plagued by the reverse causality 
problem. The main objective of this paper is to sort out the causality between trade and convergence.

\section{Empirical strategy}

\subsection{Using disaggregated trade to solve the reverse causality problem}

Some of the existing papers estimate the impact of trade on convergence by studying the historical episodes of trade liberalization or trade policies. Other papers instead analyze the impact of "trade volumes" on income convergence by either focusing on a group of countries comprising major trade partners (e.g., Ben-David, 1996) or using directly bilateral trade flows (e.g., Cyrus, 2004; Ben-David and Kimhi, 2004). No matter trade volumes or trade policies are used, the endogeneity problem is always an issue in these papers. Trade volume as an outcome variable is clearly endogenous. Trade policies determined through political process are not exogenous either as shown by the large literature on endogenous trade policies. Because disaggregated trade flows provide a convenient way to sort out the causality between trade and convergence, this paper uses a dataset on bilateral trade volumes rather than trade policies.

In the empirical literature estimating the trade impact on income convergence, a longlasting problem is the reverse causality from income convergence (or income similarity) to trade as shown by the Linder hypothesis. Even if we find a positive correlation between trade and income convergence, this does not necessarily imply causality. As noted by Ben-David (1996), "The results from this paper alone are insufficient to discern between the hypothesis that countries that trade a great deal with one another tend to converge, and the alternative hypothesis (usually associated with Linder, 1961) that 
similar countries tend to trade more." Cyrus (2004), in a bilateral trade data analysis, takes the causality issues seriously by estimating both the trade and income convergence equations with three different econometric methods: instrumental variable regressions (2SLS), fixed effects regressions and Granger causality tests. These methods are valuable improvements over previous literature, but still have many problems. For example, she uses the lagged values of endogenous regressors as instruments in both the trade and income convergence panel data regressions. This can be problematic if shocks to income and trade are persistent over time. As mentioned by Cyrus (2004), none of her instrumental regressions can pass the Sargan test of over-identification. ${ }^{8}$ In the end, she finds that countries with similar income levels always trade more with each other, but obtains mixed results on the effect of trade on income convergence. Better methods to tackle the causality problem are necessary.

Although the reverse causality problem might be unavoidable in aggregate trade analysis, it is likely that trade in certain sectors such as homogeneous product sectors are not affected by income similarity of partners (e.g., Hallak, 2006). In this paper, I use disaggregated trade data based on Rauch's product classification to solve the reverse causality problem. According to Rauch (1999), the products at 4-digit SITC level are grouped into three different categories: homogenous, reference-priced and differentiated goods. Homogenous goods (e.g., unmilled wheat and basic metals) are well-defined products listed on organized exchanges. Reference-priced goods (e.g., Polyoxyethylene) are not listed on organized exchanges, but their prices can be quoted in trade publications as "reference prices" without mentioning the names of the producers. Differentiated goods (e.g., clothing and electronics) are usually "branded" with varying quality and 
features even within refined product categories. Their production and consumption are most likely associated with countries' characteristics such as income levels. ${ }^{9}$ This is probably why homogenous products can usually be traded anonymously on organized exchanges, while the trade in differentiated products is highly influenced by producer characteristics and consumer preferences.

Therefore, we would expect that the effect of the income differences between trade partners on trade is the strongest in differentiated sectors and the weakest in homogenous sectors, with the reference-priced sectors lying in between. If trade in homogeneous sectors causes income convergence but is not affected by convergence, then the reverse causality problem would disappear in homogeneous sectors. The negative effect of trade in these sectors on income gaps can be taken as the pure evidence of trade-induced convergence. To test this conjecture, I need estimate both the trade and income convergence equations at disaggregated level.

\subsection{Estimating equations for income convergence and trade}

In this subsection, I first derive the estimating equation for income convergence based on the Solow growth model and then describe the gravity regression for bilateral trade.

There are two types of convergence: $\beta$-convergence and $\sigma$-convergence. $\beta$ convergence states that, everything else equal, initially poor countries grow faster than rich countries. $\sigma$-convergence means that the dispersion of income levels for a group of countries declines over time. This paper focuses on $\sigma$-convergence. It is well known that $\beta$-convergence is a necessary, but not a sufficient condition for $\sigma$-convergence. When we only consider two countries ( $i$ and $j$ ) as a group, the dispersion or standard deviation of 
their income levels in a given year $t$ is simply reduced to the absolute difference in their income levels, as shown below.

$$
\sigma_{i j t}=\sqrt{\frac{\left[\ln y_{i t}-\overline{\ln y_{t}}\right]^{2}+\left[\ln y_{j t}-\overline{\ln y_{t}}\right]^{2}}{2}}=\frac{\left|\ln y_{i t}-\ln y_{j t}\right|}{2}
$$

where $y_{i t}$ and $y_{j t}$ are the GDP per capita of countries $i$ and $j$ in year $t$; and $\overline{\ln y_{t}}$ is the average of $\ln \left(y_{i t}\right)$ and $\ln \left(y_{j t}\right)$.

The estimating equation of income convergence can be derived from the Solow growth model (Solow, 1956). The classic Solow growth model explains the income differences across countries by the differences in saving rates, population growth rates and technologies. This model is often augmented by human capital. As in Mankiw et al (1992), the production of country $i$ in year $t$ is assumed to be in a Cobb-Douglas form: $Y_{i t}=K_{i t}^{\alpha} H_{i t}^{\beta}\left(A_{i t} L_{i t}\right)^{1-\alpha-\beta}$, where $K$ is physical capital stock, $H$ human capital stock, $L$ labor and $A$ the level of technology. If $\alpha+\beta<1$, the steady state income per capita of country $i$ in year $t$ can be showed as:

$$
y_{i t}=A_{i 0} e^{g_{i t} t}\left(\frac{s_{k i t}}{n_{i}+g_{i}+\delta_{i}}\right)^{\frac{\alpha}{1-\alpha-\beta}}\left(\frac{s_{h i t}}{n_{i}+g_{i}+\delta_{i}}\right)^{\frac{\beta}{1-\alpha-\beta}}
$$

where $A_{i 0}$ is the initial technology level in country $i ; s_{k i t}$ and $s_{h i t}$ are the fractions of income invested in physical and human capital in country $i$ and year $t ; n$ and $g$ are the growth rates of population and technology (i.e., $L_{i t}=L_{i 0} e^{n_{i} t} ; A_{i t}=A_{i 0} e^{g_{i} t}$ ) and $\delta$ is the depreciation rate for both physical and human capital. For simplification, $n, g$, and $\delta$ are assumed to be exogenously given and constant in steady state for a give country.

Similarly, the corresponding steady state income per capita for another country $j$ in year $t$ can be written as follows: 


$$
y_{j t}=A_{j 0} e^{g_{j} t}\left(\frac{s_{k j t}}{n_{j}+g_{j}+\delta_{j}}\right)^{\frac{\alpha}{1-\alpha-\beta}}\left(\frac{s_{h j t}}{n_{j}+g_{j}+\delta_{j}}\right)^{\frac{\beta}{1-\alpha-\beta}}
$$

To derive an estimating equation for the difference in income per capita of countries $i$ and $j$, we can divide equation (2) by equation (3) and then take logs on both sides. This yields the following expression of income difference:

$$
\begin{aligned}
& \ln y_{i t}-\ln y_{j t}=\left(\ln A_{i 0}-\ln A_{j 0}\right)+\left(g_{i}-g_{j}\right) t+\frac{\alpha}{1-\alpha-\beta}\left(\ln s_{k i t}-\ln s_{k j t}\right) \\
& +\frac{\beta}{1-\alpha-\beta}\left(\ln s_{h i t}-\ln s_{h j t}\right)-\frac{\alpha+\beta}{1-\alpha-\beta}\left[\ln \left(n_{i}+g_{i}+\delta_{i}\right)-\ln \left(n_{j}+g_{j}+\delta_{j}\right)\right]
\end{aligned}
$$

In equation (4), international trade does not play a role. As discussed in the previous section, trade might affect the income gaps through many channels. Firstly, trade may reduce or increase income gaps by affecting factor prices such as wages and capital returns. Secondly, trade may affect income difference through other factors in equation (4), such as research and technology, investment in physical and human capital, and population growth. Therefore, trade is not an irrelevant factor in equation (4). Not only for the estimation of the trade impact on income convergence but also for the unbiased estimation of other coefficients, bilateral trade should be included on the right hand side of equation (4).

Augmented by bilateral trade as an additional covariate, equation (4) provides a theoretical guidance for my empirical analysis. Using a bilateral panel dataset, this paper estimates the impact of bilateral trade on the difference in income per capita of the two countries in a pair (i.e., a bilateral version of $\sigma$-convergence). Each observation in the dataset is associated with two countries ( $i$ and $j$ ) in a given year $t$. To make the estimation independent of the sign of $\left(\ln y_{i t}-\ln y_{j t}\right)$ and be consistent with the definition of the 
bilateral $\sigma$-convergence in equation (1), the absolute value of income difference is used in the regression. Accordingly, all the other differences in equation (4) are also included as absolute values in the actual regressions. The initial difference in technology levels is a proxy not just for technology, but also for resource endowments, climate, institutions, etc. It will be captured by the country pair fixed effects in the bilateral panel data analysis. The difference in the growth rates of technology $(g)$ over time is not observed and therefore can not be included in the regression. This can cause the omitted variable bias if the difference in productivity is correlated with both trade and income difference. It will be addressed by the instrumental variable regressions. Based on the previous discussion, the income difference equation can be estimated as follows:

$$
\begin{aligned}
& \left|\ln y_{i t}-\ln y_{j t}=\beta_{0}+\beta_{1} \ln \operatorname{Trade}_{i j t}+\beta_{2}\right| \ln s_{k i t}-\ln s_{k j t}\left|+\beta_{3}\right| \ln s_{h i t}-\ln s_{h j t} \mid \\
& +\beta_{4}\left|\ln \left(n_{i t}+g_{i t}+\delta_{i t}\right)-\ln \left(n_{j t}+g_{j t}+\delta_{j t}\right)\right|+a_{t}+a_{i j}+\varepsilon_{i j t}
\end{aligned}
$$

where $\operatorname{Trade}_{i j t}$ is the bilateral trade between countries $i$ and $j$ in year $t ; a_{t}$ is year dummy, which captures the time trend in income difference; $a_{i j}$ is the country pair fixed effect; and $\varepsilon_{i j t}$ is the residual term. In the dataset, $s_{k}$ and $s_{h}$ are measured by investment ratio over GDP and the share of population ever attending schools. Due to the lack of the data, the sum of $g$ and $\delta$ is set to be 0.05 in $(n+g+\delta)$ based on the traditional assumption in the literature (e.g., Mankiw et al, 1992; Cyrus, 2004). Population growth rate $(n)$ is timevarying in the data although it is assumed in the model to be constant in the steady state. The estimated $\beta_{1}$ measures the impact of trade on income difference.

To investigate the reverse causality from income convergence to trade, the bilateral trade regression is estimated in the standard gravity model framework. It is augmented by the absolute difference in the logarithms of income per capita (i.e., the "Linder term"). 


$$
\begin{aligned}
& \ln \text { Trade }_{i j t}=\gamma_{0}+\gamma_{1}\left|\ln y_{i t}-\ln y_{j t}\right|+\gamma_{2} \ln \left(G D P_{i t} * G D P_{j t}\right)+\gamma_{3} \text { Bothin }_{i j t} \\
& +\gamma_{4} \text { Onein }_{i j t}+\gamma_{5} \text { RTA }_{i j t}+\gamma_{6} C_{i j t}+\gamma_{7} \text { Alliance }_{i j t}+\gamma_{8} \text { Remote }_{i j t}+b_{t}+b_{i j}+e_{i j t}
\end{aligned}
$$

where Bothin $n_{i j t}$ dummy equals to one if both countries $i$ and $j$ were GATT/WTO members in year $t$; Onein $_{i j t}$ dummy equals to one if either $i$ or $j$ was a GATT/WTO member in year $t ; R T A_{i j t}$ dummy equals to one if $i$ and $j$ belonged to the same regional trade agreement in year $t ; C U_{i j t}$ dummy equals to one if $i$ and $j$ used the same currency in year $t$; Alliance $_{i j t}$ dummy equals to one if $i$ and $j$ were in a formal alliance in year $t$; Remote $_{i j t}$ is the distance of $i$ and $j$ to the rest of the world weighted by all the other countries' GDPs in year $t ; b_{t}$ is the year fixed effects; $b_{i j}$ is the country pair fixed effect; and $e_{i j t}$ is the residual. Many standard geographic variables such as distance, land contingency and same language dummies are not included because they are collinear with the country pair fixed effects $\left(b_{i j}\right)$. We expect that $\gamma_{1}$ is negative according to the Linder hypothesis.

Equations (5) and (6) are estimated using both aggregate and disaggregated bilateral trade data. We expect that the trade in homogeneous sectors is not significantly affected by the income differences between trade partners. If this is true, it will give us some assurance that the reverse causality problem from income difference to trade is less likely in homogeneous sectors. To address more rigorously the endogeneity problem of trade and income difference, I will also run the 2SLS and 3SLS regressions.

$\sigma$-convergence speaks about the changes in income dispersion over time for a certain group of countries. To examine a bilateral version of the $\sigma$-convergence, I focus on the within variations over time for the country pairs. Therefore, country pair fixed effects are always included in the panel data estimation of equations (5) and (6). As an important advantage of panel data analysis over cross section or pooled data analysis, country pair 
fixed effects can control for the time-invariant unobserved factors for each country pair. With the fixed effects, this paper asks the following "within" questions: ceteris paribus, do two countries trade more when their income gap becomes smaller over time; and does their income gap shrinks when two countries trade more with each other over time?

\section{Data}

The panel dataset used in this paper includes 165 countries or regions (see Appendix 1) over years $1965,1970,1975,1980,1985,1990,1995$ and 2000 . The country and year coverage is much larger than that in the existing literature. This avoids the potential selection bias from picking certain countries or time periods.

The disaggregated bilateral import data at 4-digit SITC level are from the "World Trade Flows (WTF): 1962-2000" dataset, complied by Feenstra, et al (2005). According to Rauch's classification (Rauch, 1999), products at 4-digit SITC level are grouped into three different categories: goods traded on organized exchanges (i.e., homogenous goods); goods not traded on organized exchanges but have published reference prices (i.e., reference-priced goods); and differentiated goods. The products with SITC 4-digit codes ending in A and X in the WTF dataset are not covered by the Rauch's classification. They do not belong to any of the above three categories, but are included in the total bilateral trade flows. ${ }^{11}$

The data on population, GDP per capita (in 2000 constant price), and investment share in GDP are from the Penn World Tables 6.2. The data on human capital, measured as the share of population ever attending schools, are from Barro and Lee (2000). GATT/WTO membership and regional trade agreement (RTA) data are from the WTO 
website. Currency union data are from Glick and Rose (2001). The formal alliance data are from Gibler and Sarkees (2004). They identify each formal alliance between at least two states that fall into the classes of defense pact, neutrality or non-aggression treaty, or entente agreement. The great circle distances are calculated using countries' latitudes and longitudes from the CIA Fact Book. The "remoteness" of a country is defined as the distance to the rest of the world weighted by all the other countries' GDPs in a given year. The remoteness variable for a country pair is the sum of the two countries' remoteness measures in logarithm. This remoteness variable serves as a proxy for the "index of multilateral resistance" (e.g., Anderson and Wincoop, 2003).

Table 1 lists some descriptive statistics of the variables used in the regressions.

[*** Insert Table 1 about here***]

\section{Empirical results}

\subsection{Empirical results: homogeneous vs. differentiated goods}

Tables 2 and 3 report the results from the income difference and trade regressions (5) and (6). Country pair fixed effects and year dummies are included in all of the regressions. Each table has four columns, corresponding to total trade and trade in homogeneous, reference-priced and differentiated products respectively.

[*** Insert Table 2 about here***]

Table 2 shows that trade in all of the sectors significantly reduces income gaps, and the magnitude of the coefficient is smaller in homogeneous sectors compared to other sectors. All of the differences in investment rates, human capital and $(n+g+\delta)$ positively affect income gaps as expected. The coefficients for year dummies indicate a positive 
trend in income gaps over time. These results imply that, although income gaps on average had been increasing over years from 1965 to 2000, international trade had served as a cushion against this trend.

[*** Insert Table 3 about here***]

In Table 3, income difference has a significantly negative impact on total trade, trade in reference-priced and differentiated sectors, but its effect on trade in homogeneous sectors is insignificant. The coefficients on all the other covariates have expected signs and magnitude.

These results show that the negative effects of total bilateral trade on income difference might suffer from reverse causality problem. This problem is less likely for homogeneous sectors due to the insignificant effect of income difference on trade in these sectors. Therefore the negative effect of trade in homogeneous sectors on income difference can be taken as the pure evidence of trade-induced convergence.

\subsection{Empirical results: aggregation bias?}

Although the negative effect of the trade in homogeneous sectors on income difference already provides strong support for trade-induced convergence, it is not clear whether this result is contaminated by aggregation bias. Specifically, the insignificant impact of income difference on trade in homogeneous sectors might be due to the countervailing effects on different products within homogeneous sectors. The homogeneous goods defined by Rauch (1999) can be in either manufacture or nonmanufacture sectors. It is possible that income difference affects trade in homogenous manufacture and homogeneous non-manufacture sectors in the opposite directions. As a 
result, the total effect of income difference on trade in homogeneous sectors may be rendered insignificant. To test this conjecture, I reclassify the disaggregated trade first into non-manufacture (SITC 1-digit sectors 0-5) and manufacture sectors (SITC 1-digit sectors 6-9), each of which is then grouped into three categories - homogenous, reference-priced and differentiated sectors. The regressions results using this new classification are shown in Tables 4 and 5.

[*** Insert Table 4 about here***]

Table 4 shows the results from income difference regressions. Trade in all the sectors still significantly reduces income gaps. The effects are stronger in manufacture sectors than in non-manufacture sectors; and stronger for differentiated and reference-priced goods than for homogeneous goods.

[*** Insert Table 5 about here ${ }^{* * *}$ ]

Table 5 shows the trade regression results. Income difference is insignificant in either homogeneous manufacture or homogeneous non-manufacture sectors. Trade in all the other sectors is always significantly affected by income difference, although the coefficients are more negative in manufacture sectors. These results show that the insignificant coefficient of income difference on trade in homogeneous sectors from Table 3 is less likely driven by aggregation bias. ${ }^{12}$ The results also imply that, to investigate the asymmetric effects of income gaps on trade in different sectors (i.e., the sectoral Linder hypothesis), Rauch's classification is a more suitable than the classification by manufacture and non-manufacture sectors.

\subsection{Empirical results from the 2SLS estimation}


Although the effect of the trade in homogeneous sectors on income convergence less likely suffers from the reverse causality problem, the disaggregated trade analysis alone may not solve the problem completely. For example, the omitted variables such as unobserved technology or productivity factors may still cause biased estimation of both the trade and income difference equations. The endogeneity problem is more obvious for reference-priced and differentiated sectors. Therefore a more rigorous econometric analysis is necessary. In this section, I run the 2SLS regressions separately for both the income difference and trade equations. The results are shown in Tables 6 and 7.

First, let us look at the 2SLS regressions for income difference. The natural candidates of the instruments for trade are the control variables except income difference in the trade equation (6), including the sum of GDPs, WTO, RTA, CU, alliance and remoteness. Valid instruments should be correlated to trade (i.e., "instrument relevance"), but uncorrelated to the error term in the income difference equation (i.e., "instrument exogeneity"). It is clear from Table 3 that these control variables are relevant factors to explain trade. The exogeneity of instruments or the exclusion condition is not directly testable because we do not observe the "true" error term in the income difference equation. But when multiple instruments are available, we can use the Sargan test of over-identifying restrictions to verify the exclusion conditions. Under the null, the test statistic is distributed as chi-squared in the number of over-identifying restrictions. A rejection casts doubt on the validity of at least some of the instruments.

No subset of these instruments or their lags, however, can pass the Sargan test. It is likely that these variables can affect income difference through factors other than trade, such as institutional influence, technology transfers and other international interactions. 
Fortunately, with disaggregated trade data, the trade in homogenous sectors turns out to be a good instrument for total trade. The instrument relevance condition is clearly satisfied. The previous results show that the trade in homogeneous sector is not significantly affected by income difference. Hence it is likely that the instrument exogeneity condition also holds. Because this instrument varies across country and over time, it can be used in the 2SLS panel regressions with country pair fixed effects. This is an important improvement over the traditional time-invariant instruments used for bilateral trade, such as geographic distance (e.g., Frankel and Romer, 1999; Cyrus, 2004). To take advantage of the Sargan test, trade in both homogenous non-manufacture and homogenous manufacture sectors are used as instruments. To reduce the possible simultaneity problem, the two instruments are lagged by five years.

[*** Insert Table 6 about here***]

In Table 6, the 2SLS regressions are ran for the total trade and the trade flows by sectors. ${ }^{13}$ The instruments are strong enough as shown by the F-statistics and the partial $\mathrm{R}^{2}$ in the first stage regressions. According to the Sargan test, the two instruments are valid in all the regressions except the one for differentiated sectors, where the exclusion condition is marginally rejected at $6 \%$ significance. The Sargan statistic calculated as $\mathrm{N} * \mathrm{R}^{2}$ from a regression of the IV residuals on the full set of instruments is usually large with a large sample size (N). Therefore the Sargan statistics (3.57) in the differentiated sectors is still acceptable with more than 11,000 observations. The results in Table 6 are consistent with those in Tables 2 and 4, although the trade impacts on income convergence are even larger in magnitude. 
Second, let us look at the 2SLS estimation for the trade regressions. Natural candidates of instruments for income difference are those control variables except trade in the income difference equation (5): the absolute differences in $\ln \left(s_{k}\right), \ln \left(s_{h}\right)$ and $\ln (n+g+\delta)$ between two countries in a pair. Table 2 shows that these variables are relevant factors to explain income difference. Theoretically, it is hard to think of any impact of these variables on the residual of the trade regression. Their five-year lagged variables are used as the instruments for income difference in Table 7. No other subset of these instruments or their lags can improve the results based on the Sargan test.

[*** Insert Table 7 about here $\left.{ }^{* * *}\right]$

The four columns in Table 7 are associated to the regressions on total trade and trade in the three different sectors. The instruments are very strong as shown by the F-statistics and the partial $\mathrm{R}^{2}$ in the first stage. According to the Sargan test, these instruments are at least valid for homogenous sectors. The results in Table 7 show again that income difference is highly insignificant for the trade in homogeneous sectors. They are consistent with the results in Table 3 that the Linder's hypothesis is more likely supported by the trade in differentiated sectors. The coefficients on all the other covariates differ very little from the results in Table $3 .^{14}$

\subsection{The magnitude of the estimated trade-induced convergence effect}

Is the estimated trade-induced convergence effect economically significant? Let us take the lowest estimate of trade's income-converging impact $(\beta=-0.014)$ from the first column in Table 4 as an example. As the most conservative estimate, it implies that $100 \%$ uniform increase in world trade for all the country pairs would on average reduce the 
bilateral rich-poor income ratio by $1.4 \% .{ }^{15}$ Given that the world trade had increased by more than 20 times after the World War $\mathrm{II}^{16}{ }^{16}$ the estimate implies a reduction of the average bilateral income ratio by $28 \%$ (i.e., $1.4 \% * 20$ ). It is an economically significant reduction in the world income inequality.

\section{Robustness checks}

\subsection{Robustness to different measures of trade and income difference}

The bilateral trade in this paper is measured as the logarithm of trade volumes. To check the robustness of the results, other measures of trade such as the ratio of trade over the sum of the GDPs for each country pair are also used. The main conclusions of this paper still hold. Income difference is defined as the absolute difference of the logarithms of two countries' GDP per capita. Alternatively, I also try a measure of the coefficient of variation $(\mathrm{COV})$ in income which is defined as the difference in income levels divided by their mean. This measure again yields similar results. Therefore, the results reported in this paper are not specific to certain measures of the key variables.

\subsection{Separate $2 S L S$ regressions $v$ s. joint estimation by $3 S L S$}

Previous 2SLS regression addresses the endogeneity problem separately for trade and income difference regressions. Compared to the joint estimation of both equations as a simultaneous system, separate 2SLS regressions have the advantage of robustness to the specification errors in the first stage estimation but at the expenses of efficiency loss. With separate 2 SLS, any possible misspecification in one equation would not affect the consistency of the estimation of the other equation. Facing the tradeoff between robustness and efficiency, I choose robustness over efficiency in this paper. For 
comparison purpose, however, the estimation of equations (5) and (6) as a simultaneous system is also performed. ${ }^{17}$ In this structural estimation, all of the control variables except trade and income difference are assumed exogenous to the system and uncorrelated with the disturbances. All of the exogenous variables except income difference in the trade equation are used as the instruments for trade in the current years in the income difference equation and vice versa for the trade equation. Although these instruments can not pass the Sargan tests as shown before, the results from this 3SLS estimation in Table 8 are similar to those from the separate 2SLS estimation. Because the joint estimation of both equations requires more demanding assumptions, the results are usually not necessarily better than the separate 2 SLS estimation. But Table 8 at least shows that the main conclusion of this paper is robust to different set of instrumental variables, even when they can not pass the Sargan test.

[*** Insert Table 8 about here***]

\subsection{Time-varying country fixed effects}

Recent theoretical developments in gravity model suggest that time-varying country fixed effects (e.g., year*importer and year*exporter) can fully absorb the "multilateral resistance" effects in a panel data gravity regression. These dummies are not included in my regressions for practical reasons. Using time-varying exporter and importer dummies requires very large number of interaction terms in the regressions. It is computationally cumbersome and often impossible to run regressions with such a large number of dummies. Although I was not able to run the panel regression with all these dummies, I have tried using importer and exporter dummies in the cross section data analysis for

each year in the sample. The results are again consistent with the previous findings. ${ }^{18}$ 


\section{Conclusions}

Previous empirical studies on trade and income convergence suffer from the reverse causality problem. This paper provides a new method to sort out the causality between trade and income convergence by using disaggregated bilateral trade data. Although the trade-convergence relationship is bi-directional for the trade in differentiated and reference-priced sectors, it turns out to be uni-directional in homogeneous sectors: trade in homogeneous sectors causes convergence but not vice versa. The uni-directional causal relationship from trade in homogenous sectors to income convergence can be taken as the pure evidence of trade-induced income convergence. This finding is robust to different econometric methods.

\section{Reference}

Anderson, J. and E. van Wincoop, 2003. Gravity with Gravitas: A Solution of the Land Adjacency Puzzle. American Economic Review 93(2): 170-192

Baldwin, R., 1992. Measurable Dynamic Gains from Trade. Journal of Political Economy 100 (2): 162-174.

Baldwin, R., P. Martin and G. Ottaviano, 2001. Global Income Divergence, Trade, and Industrialization: the Geography of Growth Take-offs. Journal of Economic Growth 6(2): 5-37.

Barro, R.J., 1991. Economic Growth in a Cross-Section of Countries. Quarterly Journal of Economics 106(5): 407-443.

Barro, R.J. and J.W. Lee, 2000. International Data on Educational Attainment: Updates and Implications. CID Working Paper No. 42.

Barro, R.J. and X. Sala-i-Martin, 1992. Convergence. Journal of Political Economy 100(2): 223-251.

Ben-David, D., 1993. Equalizing Exchange: Trade Liberalization and Income Convergence. Quarterly Journal of Economics 108(3): 653-679.

Ben-David, D., 1996. Trade and Convergence among Countries. Journal of International Economics 40(3-4): 279-298.

Ben-David, D. and M.B. Loewy, 1998. Free Trade, Growth, and Convergence. Journal of Economic Growth 3(4): 143-170. 
Ben-David, D. and A. Kimhi, 2004. Trade and the Rate of Income Convergence. Journal of International Trade \& Economic Development 13(5): 419-441.

Bergstrand, J., 1989. The Generalized Gravity Equation, Monopolistic Competition, and the Factor-Proportions Theory of International Trade. The Review of Economics and Statistics 71(2): 143-153.

Choi Y.C., D. Hummels and C. Xiang, 2006. Explaining Import Variety and Quality: the Role of the Income Distribution. NBER Working Paper No. 12531

Cyrus, T., 2004. Does Convergence Cause Trade, or Does Trade Cause Convergence? Journal of International Trade \& Economic Development 13(4): 397-418.

Dalgin, M., V. Trindade and D. Mitra, 2007. Inequality, Nonhomothetic Preferences, and Trade: A Gravity Approach. Forthcoming in the Southern Economic Journal.

Deardorff, A.V., 2001. Rich and Poor Countries in Neoclassical Trade and Growth. The Economic Journal 111(470): 277-294.

Dollar, D., 1992. Outward-Oriented Developing Countries Really Do Grow More Rapidly: Evidence from 95 LDCs, 1976-85. Economic Development and Cultural Change 40(3): 523-544.

Dollar, D. and A. Kraay, 2004. Trade, Growth, and Poverty. The Economic Journal 114(493): F22-F49.

Edwards, S., 1992. Trade Orientation, Distortions, and Growth in Developing Countries. Journal of Development Economics 39(1): 31-57.

Eicher, T.S., 1999. Trade, Development and Converging Growth Rates - Dynamic Gains from Trade Reconsidered. Journal of International Economics 48(2): 179-198.

Feenstra, R.C., 1996. Trade and Uneven Growth. Journal of Development Economics 49(1): 229-256.

Feenstra, R.C., R.E. Lipsey, H. Deng, A.C. Ma and H. Mo, 2005. World Trade Flows: 1962-2000. NBER Working Paper No.11040

Francois, J.F. and S. Kaplan, 1996. Aggregate Demand Shifts, Income Distribution, and the Linder Hypothesis. The Review of Economics and Statistics 78(4): 244-250.

Frankel, J. and D. Romer, 1999. Does Trade Cause Growth. American Economic Review 89(3): 379-399.

Galor O. and A. Mountford, 2006. Trade and the Great Divergence: The Family Connection. American Economic Review 96(2): 299-303

Gibler, D.M., and M. Sarkees, 2004. Measuring Alliances: the Correlates of War Formal Interstate Alliance Data Set, 1816-2000. Journal of Peace Research 41(4): 211-222.

Glick, R. and A.K. Rose, 2001. Does a Currency Union Affect Trade? The Time Series Evidence. The European Economic Review 46(6): 1125-1151.

Grossman G. and E. Helpman, 1991. Innovation and Growth in the Global Economy. The MIT Press.

Hallak, J.C., 2006. A Product-quality View of the Linder Hypothesis. Working paper, University of Michigan. 
Helpman, E., 1981. International Trade in the Presence of Product Differentiation, Economies of Scale and Monopolistic Competition: A Chamberlin-Heckscher-Ohin Approach. Journal of International Economics 11(3): 305-340.

Hunter, L., 1991. The Contribution of Nonhomothetic Preferences to Trade. Journal of International Economics 30(3-4): 345-358

Hunter, L. and J. Markusen, 1988. Per-Capita Income as a Determinant of Trade. In R. Feenstra, ed., Empirical Methods for International Trade. The MIT Press.

Hoftyzer, J., 1984. A Further Analysis of the Linder Trade Thesis. Quarterly Review of Economics and Business 24(2): 57-90.

Krugman, P., 1979. Increasing Returns, Monopolistic Competition, and International Trade. Journal of International Economics 9: 469-479.

Levine, R. and D. Renelt, 1992. A Sensitivity Analysis of Cross-Country Growth Regressions. American Economic Review 82(4): 942-963.

Linder, S., 1961. An Essay on Trade and Transformation. Stockholm: Almqvist \& Wiksell.

Mankiw, N., D. Romer, and D. Weil, 1992. A Contribution to the Empirics of Economic Growth. Quarterly Journal of Economics 107(2): 407-437.

Markusen, J.R., 1986. Explaining the Volume of Trade: An Eclectic Approach. American Economic Review 76(6): 1002-1011.

Matsuyama, K., 1992. Agricultural Productivity, Comparative Advantage, and Economic Growth. Journal of Economic Theory 58(2): 317-334.

Matsuyama, K., 2000. A Ricardian Model with a Continuum of Goods under Nonhomothetic Preferences: Demand Complementarities, Income Distribution, and North-South Trade. Journal of Political Economy 108(6): 1093-1120.

McPherson, M., M. Redfearn, and M. Tieslau, 2001. International Trade and Developing Countries: An Empirical Investigation of the Linder Hypothesis. Applied Economics 33(5): 649-657.

Milanovic, B., 2006. Economic Integration and Income Convergence: Not Such a Strong Link? Review of Economics and Statistics 88(4): 659-670.

Mitra, D. and V. Trindade, 2005. Inequality and Trade. Canadian Journal of Economics 38(5): 1253-1271.

Nakajima, T., 2003. Catch-up in Turn in a Multi-country International Trade Model with Learning-by-doing and Invention. Journal of Development Economics 72(1): 117-138.

O'Rourke, K.H., A.M. Taylor, and J. G. Williamson, 1996. Factor Price Convergence in the Late Nineteenth Century. International Economic Review 37(4): 499-530.

Rassekh, F., 1992. The Role of International Trade in the Convergence of Per Capita GDP in the OECD: 1950-85. International Economic Journal 6(4): 1-16.

Rassekh, F., 2004. The Interplay of International Trade, Economic Growth and Income Convergence: A Brief Intellectual History of Recent Developments. Journal of International Trade \& Economic Development 13(4): 371-95.

Rauch, J., 1999. Networks versus Markets in International Trade. Journal of International Economics 48(1): 7-35. 
Redding, S, 1999. Dynamic Comparative Advantage and the Welfare Effects of trade. Oxford Economic Papers 51(2): 15-39.

Rodriguez, F. and D. Rodrik, 2000. Trade Policy and Economic Growth: A Skeptic's Guide to the Cross-national Evidence. In B. Bernanke and K. Rogoff (eds.) NBER Macroeconomics Annual 2000. The MIT Press.

Sachs, J. D. and A. Warner, 1995. Economic Reform and the Process of Global Integration. Brookings Papers on Economic Activity 1(1): 1-118.

Samuelson, P., 1948. International Trade and the Equalization of Factor Prices. Economic Journal 58(1): 163-184.

Slaughter, M.J., 2001. Trade Liberalization and Per Capita Income Convergence: A Difference-in-Differences Analysis. Journal of International Economics 55(2): 203228.

Solow, R.M., 1956. A Contribution to the Theory of Economic Growth. Quarterly Journal of Economics 70(1): 65-94.

Thursby, J. and M. Thursby, 1987. Bilateral Trade Flows, the Linder Hypothesis, and Exchange Risk. The Review of Economics and Statistics 69(4): 488-495.

Ventura, J., 1997. Growth and Interdependence. Quarterly Journal of Economics 112(1): 57-84.

Williamson, J., 1996. Globalization, Convergence, and History. Journal of Economic History 56(2): 277-306.

Young, A, 1991. Learning by Doing and the Dynamic Effects of International Trade. Quarterly Journal of Economics 106(2): 369-405.

Table 1: Variables' descriptive statistics

\begin{tabular}{|c|c|c|c|c|c|}
\hline Variable & Obs & Mean & S.D. & Min & Max \\
\hline \multicolumn{6}{|l|}{ Trade Equation } \\
\hline $\ln$ (Total Trade) & 85562 & 8.61 & 3.21 & 0 & 19.27 \\
\hline $\ln$ (Trade in Hom.) & 60395 & 8.07 & 2.90 & 0 & 17.60 \\
\hline $\ln$ (Trade in Ref.) & 60807 & 7.73 & 2.92 & 0 & 17.37 \\
\hline $\ln$ (Trade in Dif.) & 70454 & 7.70 & 3.23 & 0 & 18.78 \\
\hline $\ln (\mathrm{GDPi} * \mathrm{GDPj})$ & 69025 & 35.90 & 2.47 & 24.35 & 45.35 \\
\hline Both in WTO & 85644 & 0.44 & 0.50 & 0 & 1 \\
\hline One in WTO & 85644 & 0.45 & 0.50 & 0 & 1 \\
\hline RTA & 85644 & 0.09 & 0.29 & 0 & 1 \\
\hline Currency Union & 85644 & 0.02 & 0.15 & 0 & 1 \\
\hline Alliance & 85644 & 0.08 & 0.27 & 0 & 1 \\
\hline Remoteness & 83849 & 4.31 & 0.07 & 4.04 & 4.50 \\
\hline \multicolumn{6}{|l|}{ Income Equation } \\
\hline$|\ln [y(\mathrm{i})]-\ln [\mathrm{y}(\mathrm{j})]|$ & 69025 & 1.33 & 0.96 & 0 & 5.14 \\
\hline$|\ln [\operatorname{sk}(\mathrm{i})]-\ln [\operatorname{sk}(\mathrm{j})]|$ & 69744 & 0.76 & 0.60 & 0 & 3.81 \\
\hline$|\ln [\operatorname{sh}(\mathrm{i})]-\ln [\operatorname{sh}(\mathrm{j})]|$ & 45047 & 1.79 & 1.32 & 0 & 6.19 \\
\hline$|\ln [\operatorname{ng} \delta(\mathrm{i})]-\ln [\operatorname{ng} \delta(\mathrm{j})]|$ & 76383 & 0.22 & 0.18 & 0 & 3.63 \\
\hline
\end{tabular}

"Hom.", "Ref." and "Dif." refer to homogenous, reference-priced and differentiated sectors respectively; "sk", "sh", "ng $\delta$ " refer to $s_{k}, s_{h}$ and $(n+g+\delta)$ in the text respectively;

Please refer to the text for the definitions of these variables. 
Table 2: The impact of trade on income difference

\begin{tabular}{|c|c|c|c|c|}
\hline & $(1)$ & $(2)$ & (3) & (4) \\
\hline $\ln$ (Total Trade) & $\begin{array}{l}-0.031 * * * \\
(0.002)\end{array}$ & & & \\
\hline $\ln$ (Trade in Hom.) & & $\begin{array}{l}-0.015^{* * * *} \\
(0.002)\end{array}$ & & \\
\hline $\ln$ (Trade in Ref.) & & & $\begin{array}{l}-0.029 * * * \\
(0.002)\end{array}$ & \\
\hline $\ln$ (Trade in Dif.) & & & & $\begin{array}{l}-0.035 * * * \\
(0.002)\end{array}$ \\
\hline$|\ln [\operatorname{sk}(\mathrm{i})]-\ln [\operatorname{sk}(\mathrm{j})]|$ & $\begin{array}{l}0.072 * * * \\
(0.009)\end{array}$ & $\begin{array}{l}0.069 * * * \\
(0.010)\end{array}$ & $\begin{array}{l}0.058 * * * \\
(0.010)\end{array}$ & $\begin{array}{l}0.067 * * * \\
(0.010)\end{array}$ \\
\hline$|\ln [\operatorname{sh}(i)]-\ln [\operatorname{sh}(j)]|$ & $\begin{array}{l}0.070 * * * \\
(0.005)\end{array}$ & $\begin{array}{l}0.054 * * * \\
(0.006)\end{array}$ & $\begin{array}{l}0.061 * * * \\
(0.006)\end{array}$ & $\begin{array}{l}0.069 * * * \\
(0.006)\end{array}$ \\
\hline$|\ln [\mathrm{ng} \delta(\mathrm{i})]-\ln [\mathrm{ng} \delta(\mathrm{j})]|$ & $\begin{array}{l}0.807 * * * \\
(0.037)\end{array}$ & $\begin{array}{l}0.743 * * * \\
(0.042)\end{array}$ & $\begin{array}{l}0.696 * * * \\
(0.039)\end{array}$ & $\begin{array}{l}0.799 * * * \\
(0.040)\end{array}$ \\
\hline year $=1970$ & $\begin{array}{l}0.004 \\
(0.005)\end{array}$ & $\begin{array}{l}0.008 \\
(0.006)\end{array}$ & $\begin{array}{l}0.020 * * * \\
(0.006)\end{array}$ & $\begin{array}{l}0.014 * * \\
(0.006)\end{array}$ \\
\hline year $=1975$ & $\begin{array}{l}0.070 * * * \\
(0.006)\end{array}$ & $\begin{array}{l}0.051 * * * \\
(0.007)\end{array}$ & $\begin{array}{l}0.070 * * * \\
(0.007)\end{array}$ & $\begin{array}{l}0.078 * * * \\
(0.007)\end{array}$ \\
\hline year $=1980$ & $\begin{array}{l}0.071 * * * \\
(0.007)\end{array}$ & $\begin{array}{l}0.035 * * * \\
(0.008)\end{array}$ & $\begin{array}{l}0.062 * * * \\
(0.008)\end{array}$ & $\begin{array}{l}0.081 * * * \\
(0.008)\end{array}$ \\
\hline year $=1985$ & $\begin{array}{l}0.086 * * * \\
(0.008)\end{array}$ & $\begin{array}{l}0.049 * * * \\
(0.009)\end{array}$ & $\begin{array}{l}0.074 * * * \\
(0.009)\end{array}$ & $\begin{array}{l}0.095 * * * \\
(0.009)\end{array}$ \\
\hline year $=1990$ & $\begin{array}{l}0.172 * * * \\
(0.009)\end{array}$ & $\begin{array}{l}0.107 * * * \\
(0.010)\end{array}$ & $\begin{array}{l}0.154 * * * \\
(0.010)\end{array}$ & $\begin{array}{l}0.190 * * * \\
(0.010)\end{array}$ \\
\hline year $=1995$ & $\begin{array}{l}0.266 * * * \\
(0.010)\end{array}$ & $\begin{array}{l}0.175 * * * \\
(0.011)\end{array}$ & $\begin{array}{l}0.210 * * * \\
(0.011)\end{array}$ & $\begin{array}{l}0.275 * * * \\
(0.011)\end{array}$ \\
\hline year $=2000$ & $\begin{array}{l}0.295 * * * \\
(0.011)\end{array}$ & $\begin{array}{l}0.190 * * * \\
(0.012)\end{array}$ & $\begin{array}{l}0.224 * * * \\
(0.012)\end{array}$ & $\begin{array}{l}0.304 * * * \\
(0.012)\end{array}$ \\
\hline Observations & 42665 & 32472 & 32684 & 36416 \\
\hline R-squared & 0.91 & 0.92 & 0.92 & 0.92 \\
\hline
\end{tabular}

Robust standard errors in parentheses (clustered by country pairs);

* significant at $10 \%$; * significant at $5 \%$; *** significant at $1 \%$;

Country pair fixed effects are included in all the regressions;

Base year is 1965 in all the regressions;

"Hom.," "Ref." and "Dif." refer to homogenous, reference-priced and differentiated sectors respectively;

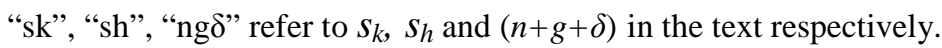


Table 3: The impact of income difference on trade

\begin{tabular}{|c|c|c|c|c|}
\hline & $(1)$ & $(2)$ & (3) & (4) \\
\hline \multirow{3}{*}{$|\ln [y(\mathrm{i})]-\ln [\mathrm{y}(\mathrm{j})]|$} & Total Trade & Trade in Hom. & Trade in Ref. & Trade in Dif. \\
\hline & $-0.126^{* * *}$ & -0.040 & $-0.205^{* * *}$ & $-0.173 * * *$ \\
\hline & $(0.032)$ & $(0.038)$ & $(0.036)$ & $(0.035)$ \\
\hline \multirow[t]{2}{*}{$\ln \left(\mathrm{GDP}^{*}{ }^{*} \mathrm{GDPj}\right)$} & $1.082 * * *$ & $0.699 * * *$ & $0.990 * * *$ & $1.151 * * *$ \\
\hline & $(0.032)$ & $(0.038)$ & $(0.036)$ & $(0.035)$ \\
\hline \multirow[t]{2}{*}{ Both in WTO } & $0.272 * * *$ & $0.157 *$ & $0.387 * * *$ & $0.236 * * *$ \\
\hline & $(0.063)$ & $(0.083)$ & $(0.075)$ & $(0.071)$ \\
\hline \multirow[t]{2}{*}{ One in WTO } & $0.235 * * *$ & 0.081 & $0.260 * * *$ & $0.111^{*}$ \\
\hline & $(0.059)$ & $(0.076)$ & $(0.070)$ & $(0.066)$ \\
\hline \multirow[t]{2}{*}{ RTA } & $0.330 * * *$ & $0.234 * * *$ & $0.290 * * *$ & $0.339 * * *$ \\
\hline & $(0.037)$ & $(0.044)$ & $(0.039)$ & $(0.039)$ \\
\hline \multirow[t]{2}{*}{ Currency Union } & $0.352 *$ & $0.423 * *$ & $0.441 * *$ & $0.363^{*}$ \\
\hline & $(0.188)$ & $(0.208)$ & $(0.212)$ & $(0.198)$ \\
\hline \multirow[t]{2}{*}{ Alliance } & $0.113^{*}$ & 0.114 & 0.013 & 0.092 \\
\hline & $(0.059)$ & $(0.073)$ & $(0.065)$ & $(0.066)$ \\
\hline \multirow[t]{2}{*}{ Remoteness } & $5.366 * * *$ & $5.398 * * *$ & $5.433 * * *$ & $4.258 * * *$ \\
\hline & $(0.612)$ & $(0.804)$ & $(0.719)$ & $(0.662)$ \\
\hline Observations & 68956 & 49188 & 49779 & 57028 \\
\hline R-squared & 0.86 & 0.81 & 0.85 & 0.88 \\
\hline
\end{tabular}

Robust standard errors in parentheses (clustered by country pairs);

* significant at $10 \%$; * significant at $5 \%$; *** significant at $1 \%$;

Country pair fixed effects are included in all the regressions;

Year dummies are included in all the regressions, but not shown to save space;

"Hom.", "Ref." and "Dif." refer to homogenous, reference-priced and differentiated sectors respectively. 
Table 4: The impact of trade on income difference (aggregation bias)

\begin{tabular}{|c|c|c|c|c|c|c|}
\hline & $(1)$ & (2) & (3) & (4) & $(5)$ & (6) \\
\hline \multicolumn{7}{|l|}{ Non-manufacture: } \\
\hline $\ln$ (Trade in Hom.) & $\begin{array}{l}-0.014 * * * \\
(0.002)\end{array}$ & & & & & \\
\hline $\ln$ (Trade in Ref.) & & $\begin{array}{l}-0.022 * * * \\
(0.002)\end{array}$ & & & & \\
\hline $\ln$ (Trade in Dif.) & & & $\begin{array}{l}-0.027 * * * \\
(0.003)\end{array}$ & & & \\
\hline \multicolumn{7}{|l|}{ Manufacture: } \\
\hline $\ln$ (Trade in Hom.) & & & & $\begin{array}{l}-0.016 \text { **** } \\
(0.002)\end{array}$ & & \\
\hline $\ln$ (Trade in Ref.) & & & & & $\begin{array}{l}-0.031 \text { *** } \\
(0.002)\end{array}$ & \\
\hline $\ln$ (Trade in Dif.) & & & & & & $\begin{array}{l}-0.036 * * * \\
(0.002)\end{array}$ \\
\hline$|\ln [\operatorname{sk}(\mathrm{i})]-\ln [\operatorname{sk}(\mathrm{j})]|$ & $\begin{array}{l}0.065^{* * *} \\
(0.010)\end{array}$ & $\begin{array}{l}0.053 * * * \\
(0.010)\end{array}$ & $\begin{array}{l}0.060 * * * \\
(0.011)\end{array}$ & $\begin{array}{l}0.077 * * * \\
(0.016)\end{array}$ & $\begin{array}{l}0.057 * * * \\
(0.012)\end{array}$ & $\begin{array}{l}0.063 * * * \\
(0.010)\end{array}$ \\
\hline$|\ln [\operatorname{sh}(i)]-\ln [\operatorname{sh}(j)]|$ & $\begin{array}{l}0.054 * * * \\
(0.006)\end{array}$ & $\begin{array}{l}0.055^{* * *} * \\
(0.006)\end{array}$ & $\begin{array}{l}0.058 * * * \\
(0.006)\end{array}$ & $\begin{array}{l}0.044 * * * \\
(0.007)\end{array}$ & $\begin{array}{l}0.063 * * * \\
(0.007)\end{array}$ & $\begin{array}{l}0.068 * * * \\
(0.006)\end{array}$ \\
\hline$|\ln [\operatorname{ng} \delta(\mathrm{i})]-\ln [\mathrm{ng} \delta(\mathrm{j})]|$ & $\begin{array}{l}0.736 * * * \\
(0.042)\end{array}$ & $\begin{array}{l}0.648 * * * \\
(0.040)\end{array}$ & $\begin{array}{l}0.652 * * * \\
(0.039)\end{array}$ & $\begin{array}{l}0.539 * * * \\
(0.062)\end{array}$ & $\begin{array}{l}0.679 * * * \\
(0.047)\end{array}$ & $\begin{array}{l}0.827 * * * \\
(0.043)\end{array}$ \\
\hline Observations & 31234 & 30016 & 28321 & 15767 & 23716 & 33633 \\
\hline R-squared & 0.92 & 0.93 & 0.93 & 0.93 & 0.93 & 0.92 \\
\hline
\end{tabular}

Robust standard errors in parentheses (clustered by country pairs);

$*$ significant at $10 \%$;* significant at $5 \%$; *** significant at $1 \%$;

Country pair fixed effects and year dummies are included in all the regressions;

"Hom.", "Ref." and "Dif." refer to homogenous, reference-priced and differentiated sectors respectively;

"sk", "sh", "ng $\delta$ " refer to $s_{k}, s_{h}$ and $(n+g+\delta)$ in the text respectively.

Table 5: The impact of income difference on trade (aggregation bias)

\begin{tabular}{|c|c|c|c|c|c|c|}
\hline & \multicolumn{3}{|c|}{ Non-manufacture Sectors } & \multicolumn{3}{|c|}{ Manufacture Sectors } \\
\hline & (1) & (2) & (3) & (4) & (5) & (6) \\
\hline & Hom. & Ref. & Dif. & Hom. & Ref. & Dif. \\
\hline \multirow[t]{2}{*}{$|\ln [y(\mathrm{i})]-\ln [\mathrm{y}(\mathrm{j})]|$} & -0.036 & $-0.093 * *$ & $-0.099 * * *$ & -0.101 & $-0.342 * * *$ & $-0.225 * * *$ \\
\hline & $(0.039)$ & $(0.038)$ & $(0.038)$ & $(0.071)$ & $(0.045)$ & $(0.038)$ \\
\hline \multirow{2}{*}{$\ln \left(\mathrm{GDPi}^{*} \mathrm{GDPj}\right)$} & $0.664 * * *$ & $0.945^{* * *}$ & $0.805 * * *$ & $0.830 * * *$ & $1.007 * * *$ & $1.173 * * *$ \\
\hline & $(0.039)$ & $(0.038)$ & $(0.036)$ & $(0.061)$ & $(0.043)$ & $(0.038)$ \\
\hline \multirow[t]{2}{*}{ Both in WTO } & 0.102 & $0.373 * * *$ & $0.136^{*}$ & $0.467 * * *$ & $0.394 * * *$ & $0.196 * *$ \\
\hline & $(0.086)$ & $(0.078)$ & $(0.079)$ & $(0.157)$ & $(0.101)$ & $(0.077)$ \\
\hline \multirow[t]{2}{*}{ One in WTO } & 0.050 & $0.242 * * *$ & 0.064 & 0.158 & $0.275 * * *$ & 0.084 \\
\hline & $(0.080)$ & $(0.073)$ & $(0.075)$ & $(0.145)$ & $(0.094)$ & $(0.072)$ \\
\hline \multirow[t]{2}{*}{ RTA } & $0.220 * * *$ & $0.200 * * *$ & $0.302 * * *$ & $0.268 * * *$ & $0.456 * * *$ & $0.347 * * *$ \\
\hline & $(0.046)$ & $(0.041)$ & $(0.040)$ & $(0.065)$ & $(0.048)$ & $(0.042)$ \\
\hline \multirow{2}{*}{ Currency Union } & $0.393 *$ & $0.378 *$ & 0.236 & $0.701 * *$ & $0.810 * * *$ & $0.589 * * *$ \\
\hline & $(0.201)$ & $(0.225)$ & $(0.216)$ & $(0.296)$ & $(0.212)$ & $(0.200)$ \\
\hline \multirow[t]{2}{*}{ Alliance } & $0.175 * *$ & $-0.114 *$ & 0.056 & 0.063 & 0.112 & 0.046 \\
\hline & $(0.076)$ & $(0.066)$ & $(0.071)$ & $(0.107)$ & $(0.087)$ & $(0.074)$ \\
\hline \multirow[t]{2}{*}{ Remoteness } & $5.778 * * *$ & $5.399 * * *$ & $2.961 * * *$ & $3.948 * * *$ & $3.769 * * *$ & $3.955 * * *$ \\
\hline & $(0.828)$ & $(0.745)$ & $(0.752)$ & (1.312) & $(0.935)$ & $(0.706)$ \\
\hline Observations & 47212 & 44940 & 41771 & 21188 & 34583 & 52106 \\
\hline R-squared & 0.80 & 0.85 & 0.86 & 0.92 & 0.93 & 0.93 \\
\hline
\end{tabular}

Notes: see the previous table. 
Table 6: The impact of trade on income difference, 2SLS

\begin{tabular}{|c|c|c|c|c|}
\hline & $(1)$ & $(2)$ & (3) & $(4)$ \\
\hline $\ln$ (Total Trade) & $\begin{array}{l}-0.141 * * * \\
(0.014)\end{array}$ & & & \\
\hline $\ln$ (Trade in Hom.) & & $\begin{array}{l}-0.084 * * * \\
(0.009)\end{array}$ & & \\
\hline $\ln$ (Trade in Ref.) & & & $\begin{array}{l}-0.158 * * * \\
(0.019)\end{array}$ & \\
\hline $\ln$ (Trade in Dif.) & & & & $\begin{array}{l}-0.181 * * * \\
(0.021)\end{array}$ \\
\hline$|\ln [\operatorname{sk}(\mathrm{i})]-\ln [\operatorname{sk}(\mathrm{j})]|$ & $\begin{array}{l}0.092 * * * \\
(0.011)\end{array}$ & $\begin{array}{l}0.111 * * * \\
(0.011)\end{array}$ & $\begin{array}{l}0.085 * * * \\
(0.012)\end{array}$ & $\begin{array}{l}0.079 * * * \\
(0.013)\end{array}$ \\
\hline$|\ln [\operatorname{sh}(\mathrm{i})]-\ln [\operatorname{sh}(\mathrm{j})]|$ & $\begin{array}{l}0.027 * * * \\
(0.005)\end{array}$ & $\begin{array}{l}0.014 * * \\
(0.006)\end{array}$ & $\begin{array}{l}0.031 * * * \\
(0.006)\end{array}$ & $\begin{array}{l}0.033 * * * \\
(0.006)\end{array}$ \\
\hline$|\ln [\operatorname{ng} \delta(\mathrm{i})]-\ln [\operatorname{ng} \delta(\mathrm{j})]|$ & $\begin{array}{l}0.365 * * * \\
(0.034)\end{array}$ & $\begin{array}{l}0.336 * * * \\
(0.036)\end{array}$ & $\begin{array}{l}0.308 * * * \\
(0.037)\end{array}$ & $\begin{array}{l}0.386 * * * \\
(0.039)\end{array}$ \\
\hline \multicolumn{5}{|l|}{ IVs in First Stage } \\
\hline Partial R2 & 0.05 & 0.07 & 0.03 & 0.02 \\
\hline F-statistics & $249 * * *$ & $319 * * *$ & $119 * * *$ & $95 * * *$ \\
\hline$P$-value for $I V=0$ & {$[0.00]$} & {$[0.00]$} & {$[0.00]$} & {$[0.00]$} \\
\hline Sargan statistic & 0.00 & 0.16 & 0.68 & $3.57 *$ \\
\hline $\mathrm{P}$-value of OI test & [0.99] & [0.69] & {$[0.41]$} & {$[0.06]$} \\
\hline Observations & 11710 & 11347 & 11268 & 11414 \\
\hline
\end{tabular}

The IVs for trade are the five-year lagged trade in homogenous non-manufacture and homogenous manufacture sectors;

Standard errors in parentheses; * significant at $10 \%$; * significant at 5\%; *** significant at $1 \%$;

Country pair fixed effects and year dummies are included in all the regressions;

"Hom.", "Ref." and "Dif." refer to homogenous, reference-priced and differentiated sectors respectively. 
Table 7: The impact of income difference on trade, 2SLS

\begin{tabular}{|c|c|c|c|c|}
\hline & $(1)$ & (2) & (3) & (4) \\
\hline & Total Trade & Trade in Hom. & Trade in Ref. & Trade in Dif. \\
\hline \multirow{2}{*}{$|\ln [y(i)]-\ln [y(j)]|$} & $-0.182 *$ & -0.107 & $-0.542 * * *$ & $-0.459 * * *$ \\
\hline & $(0.099)$ & $(0.152)$ & $(0.125)$ & $(0.106)$ \\
\hline \multirow[t]{2}{*}{$\ln (\mathrm{GDPi}$ *GDPj $)$} & $1.163 * * *$ & $0.780 * * *$ & $1.043 * * *$ & $1.207 * * *$ \\
\hline & $(0.045)$ & $(0.064)$ & $(0.052)$ & $(0.048)$ \\
\hline \multirow[t]{2}{*}{ Both in WTO } & -0.028 & 0.092 & $0.333 * * *$ & -0.025 \\
\hline & $(0.071)$ & $(0.102)$ & $(0.088)$ & $(0.079)$ \\
\hline \multirow[t]{2}{*}{ One in WTO } & -0.013 & 0.018 & $0.134 *$ & -0.081 \\
\hline & $(0.065)$ & $(0.094)$ & $(0.082)$ & $(0.073)$ \\
\hline \multirow[t]{2}{*}{ RTA } & $0.353 * * *$ & $0.256 * * *$ & $0.319 * * *$ & $0.392 * * *$ \\
\hline & $(0.035)$ & $(0.044)$ & $(0.038)$ & $(0.037)$ \\
\hline \multirow[t]{2}{*}{ Currency Union } & $0.793 * *$ & $0.976^{* *}$ & $1.015^{* *}$ & $0.933 * *$ \\
\hline & $(0.404)$ & $(0.472)$ & $(0.411)$ & $(0.409)$ \\
\hline \multirow[t]{2}{*}{ Alliance } & 0.099 & 0.106 & 0.081 & $0.154 * *$ \\
\hline & $(0.069)$ & $(0.082)$ & $(0.071)$ & $(0.070)$ \\
\hline \multirow{2}{*}{ Remoteness } & $4.468 * * *$ & $4.980 * * *$ & $6.361 * * *$ & $4.893 * * *$ \\
\hline & $(0.627)$ & $(0.862)$ & $(0.725)$ & $(0.681)$ \\
\hline \multicolumn{5}{|l|}{ IVs in First Stage } \\
\hline Partial R2 & 0.08 & 0.06 & 0.07 & 0.08 \\
\hline F-statistics & $727 * * *$ & $456 * * *$ & $512 * * *$ & $673 * * *$ \\
\hline$P$-value for $I V=0$ & {$[0.00]$} & {$[0.00]$} & {$[0.00]$} & {$[0.00]$} \\
\hline Sargan statistic & $24.42 * * *$ & 1.94 & $21.23 * * *$ & $40.20 * * *$ \\
\hline $\mathrm{P}$-value of OI test & {$[0.00]$} & {$[0.38]$} & {$[0.00]$} & {$[0.00]$} \\
\hline Observations & 31865 & 25002 & 25574 & 28011 \\
\hline
\end{tabular}

The IVs for income gap are five-year lagged $\mid \ln [\operatorname{sk}(\mathrm{i})-\ln [\operatorname{sk}(\mathrm{j})]|,| \ln [\operatorname{sh}(\mathrm{i})]-\ln [\operatorname{sh}(\mathrm{j})] \mid$ and $|\ln [\operatorname{ng} \delta(\mathrm{i})]-\ln [\operatorname{ng} \delta(\mathrm{j})]|$; Standard errors in parentheses; * significant at 10\%; ** significant at 5\%; *** significant at $1 \%$;

Country pair fixed effects and year dummies are included in all the regressions;

"Hom.", "Ref." and "Dif." refer to homogenous, reference-priced and differentiated sectors respectively. 
Table 8: Joint estimation of the trade and income equations, 3SLS

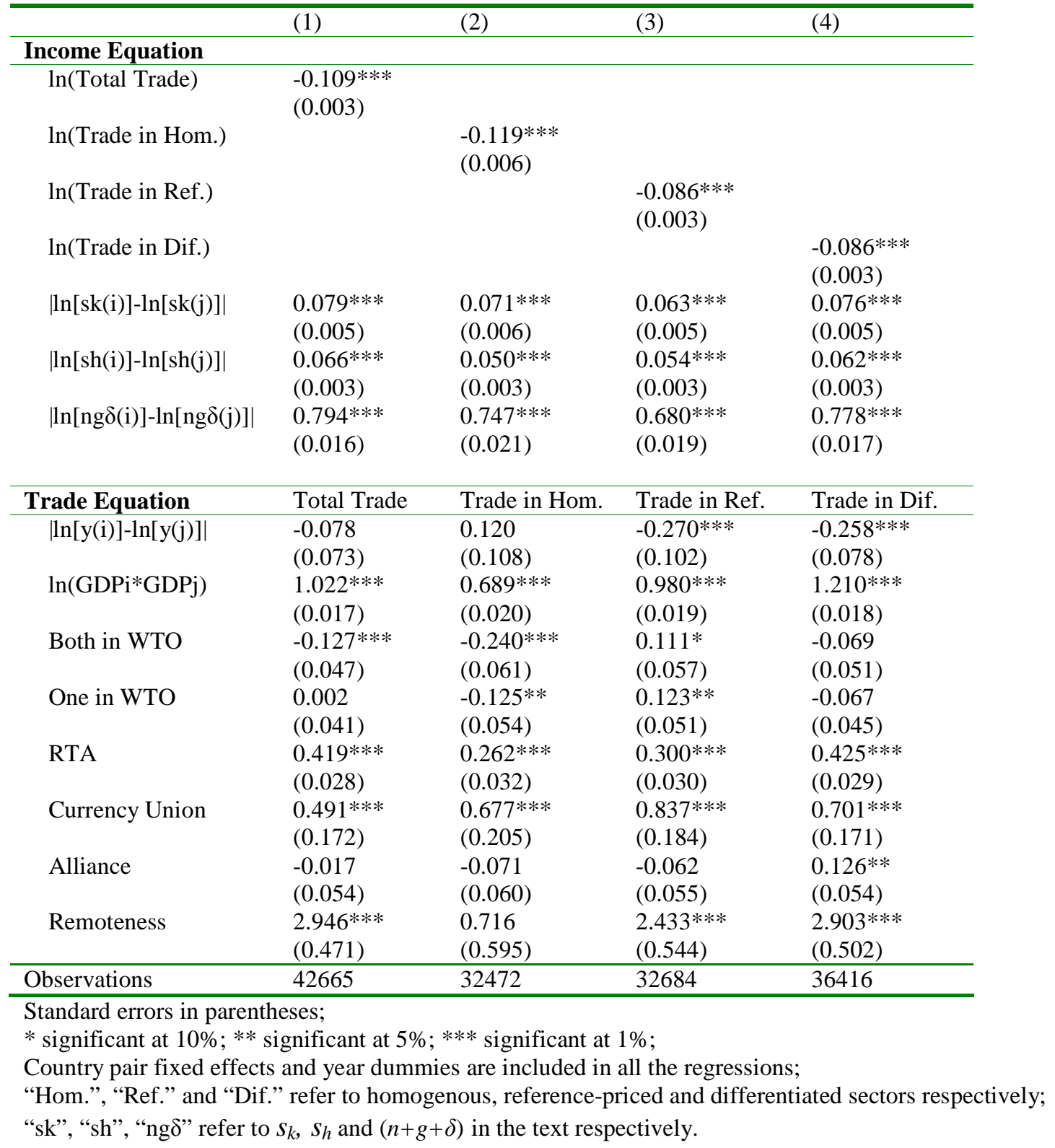


Appendix 1: Countries covered in this paper (165)

\begin{tabular}{|c|c|c|c|}
\hline Afghanistan & Dominican Rep. & Laos & Samoa \\
\hline Albania & Ecuador & Latvia & Saudi Arabia \\
\hline Algeria & Egypt & Lebanon & Senegal \\
\hline Angola & El Salvador & Liberia & Serbia \& Montenegro \\
\hline Argentina & Equatorial Guinea & Libya & Seychelles \\
\hline Armenia & Estonia & Lithuania & Sierra Leone \\
\hline Australia & Ethiopia & Macao & Singapore \\
\hline Austria & Fiji & Macedonia & Slovakia \\
\hline Azerbaijan & Finland & Madagascar & Slovenia \\
\hline Bahamas & France & Malawi & Somalia \\
\hline Bahrain & Gabon & Malaysia & South Africa \\
\hline Bangladesh & Gambia & Mali & Spain \\
\hline Barbados & Georgia & Malta & Sri Lanka \\
\hline Belarus & Germany & Mauritania & Sudan \\
\hline Belgium & Ghana & Mauritius & Suriname \\
\hline Belize & Greece & Mexico & Sweden \\
\hline Benin & Guatemala & Moldova & Switzerland \\
\hline Bermuda & Guinea & Mongolia & Syria \\
\hline Bolivia & Guinea-Bissau & Morocco & Taiwan \\
\hline Bosnia \& Herzegovina & Guyana & Mozambique & Tajikistan \\
\hline Brazil & Haiti & Nepal & Tanzania \\
\hline Bulgaria & Honduras & Netherlands & Thailand \\
\hline Burkina Faso & Hong Kong & Netherlands Antilles & Togo \\
\hline Burundi & Hungary & New Zealand & Trinidad \& Tobago \\
\hline Cambodia & Iceland & Nicaragua & Tunisia \\
\hline Cameroon & India & Niger & Turkey \\
\hline Canada & Indonesia & Nigeria & Turkmenistan \\
\hline Central African Rep. & Iran & Norway & Uganda \\
\hline Chad & Iraq & Oman & Ukraine \\
\hline Chile & Ireland & Pakistan & United Arab Emirates \\
\hline China & Israel & Panama & UK \\
\hline Colombia & Italy & Papua New Guinea & USA \\
\hline Congo, Dem. Rep. & Jamaica & Paraguay & Uruguay \\
\hline Congo, Rep. of & Japan & Peru & Uzbekistan \\
\hline CostaRica & Jordan & Philippines & Venezuela \\
\hline Cote D Ivoire & Kazakhstan & Poland & Vietnam \\
\hline Croatia & Kenya & Portugal & Yemen, Rep. of \\
\hline Cuba & Kiribati & Qatar & Zambia \\
\hline Cyprus & Korea, North & Romania & Zimbabwe \\
\hline Czech Rep. & Korea, South & Russia & \\
\hline Denmark & Kuwait & Rwanda & \\
\hline Djibouti & Kyrgyzstan & Saint Kitts \& Nevis & \\
\hline
\end{tabular}




\section{Endnotes:}

\footnotetext{
${ }^{1}$ See, e.g., Barro (1991); Barro and Sala-i-Martin (1992); Levine and Renelt (1992); Mankiw et al (1992).

${ }^{2}$ Besides its effect on investment in physical capital, trade may cause income convergence or divergence by affecting the investment in human capital and population growth (e.g., Eicher, 1999; Galor and Mountford, 2006).

${ }^{3}$ Similarly, trade can also help poor countries growth faster through institutional spillovers (e.g., corporate governance, law and order).

${ }^{4}$ See also Bergstrand (1989), Matsuyama (2000) and Mitra and Trindade (2005) among others for theories on trade and non-homothetic preference.

${ }^{5}$ See Rassekh (2004) for a recent survey of the literature on trade, growth and convergence.

${ }^{6}$ These findings are consistent with many studies on trade and growth (e.g., Dollar, 1992; Edwards, 1992; Dollar and Kraay, 2004). They find a positive relationship between trade and faster economic growth in developing countries.

${ }^{7}$ Francois and Kaplan (1996), Dalgin et al (2007), and Choi et al (2006) go beyond the similarity in income levels to consider the similarity in income distributions.

${ }^{8}$ As for Granger causality tests, they strictly speaking do not apply directly to panel data setting, especially when the time demission is short $(\mathrm{T}=8)$.

${ }^{9}$ Sometimes the distinctions between these categories are subtle. For example, the following three products at 4-digit SITC level are classified as homogenous, reference-priced and differentiated goods respectively: (6342) densified wood and reconstituted wood; (6343) plywood of wood sheets with each ply not over 6mm thick; (6344) plywood, not elsewhere specified, veneered panels and similar laminated wood.

${ }^{10} \beta_{4}$ is expected to have a positive sign although the corresponding coefficient in equation (4) is negative. This difference is due to using the absolute value of the difference in $\ln (n+g+\delta)$ in equation (5).

${ }^{11}$ In the WTF dataset, the SITC 4-digit codes ending in A are the "aggregates" of all the 4-digit products; the SITC 4-digit codes ending in X are the "extra" trade of some the 4-digit products. There is no way to separate these imports into individual 4-digit categories. See Feenstra et al (2005) for more details.

${ }^{12}$ Further investigation into the Linder hypothesis at 3-digit SITC levels can be found in Hallak (2006).

${ }^{13}$ Please note that the instruments are not collinear with the trade in homogeneous sectors in the second column in Table 6 as the instruments are lagged by five years.

${ }^{14}$ An autocorrelation-efficient two-step GMM estimation is also used for the regressions in Tables 6 and 7 , and yields very similar results.

${ }^{15}$ To avoid the complication from trade diversion (i.e., increased trade with some partners at the expenses of decreased trade with others), I assume a uniform increase in bilateral trade for all the country pairs.

${ }^{16}$ According to the world trade data from the IMF Direction of Trade Statistics, the world trade in real term had increased by 20 times from 1948 to 2003.

${ }^{17}$ All the variables are demeaned by country pairs over years to get rid of the country pair fixed effects before the 3SLS estimation.

${ }^{18}$ Similar to the previous regressions, the income difference always negatively and significantly affects the trade in differentiated sectors, but is highly insignificant in homogeneous sectors in six out of the eight years in my sample.
} 